\title{
Вакуумна, плазмова
}

\section{ма квантова електроніка}

УДК 621.38

DOI: $10.20535 / 2523-4455.2018 .23 .1 .105252$

\section{Моделювання надвисокочастотного генератора плазми}

\author{
Перевертайло В. В., ORCID 0000-0001-5706-5946 \\ e-mail vladimir_mj@ukr.net \\ Національний технічний університет України \\ "Київський політехнічний інститут імені Ігоря Сікорського" kpi.ua \\ Київ, Україна
}

Реферат-Представлено результати 3D моделювання хвилеводно-резонаторного тракту спільно 3 газорозрядною камерою, шляхом чого було розраховано геометричні параметри НВЧ генератора в узгодженому режимі 3 максимальною передачею енергії від джерела НВЧ потужності до області, де буде відбуватись генерація плазми. Розрахунок проводився, виходячи з умови подальшого сумісного використання пристрою з системою магнетронного розпилення і призначений він для активації інертного газу. У даній роботі представлено аналіз складових частин генератора плазми з урахуванням розрахунків, опис схеми роботи системи та принцип роботи НВЧ генератора плазми.

Бібл. 12, рис. 9.

Ключові слова - надвисокочастотний генератор плазми; ЗD моделювання; НВЧ тракт; хвилевід.

\section{I. ВСТУП}

Сьогодні плазмові технології мають широке застосування [1-6] та продовжують розвиватись системи низького тиску для нетермічних методів обробки і нанесення покриттів [7-9].

Для впровадженням в технологію плазмових методів потрібне нове ефективне обладнання, у даному випадку НВЧ генератори плазми, і необхідні ефективні методи його проектування. Зараз при розробці технологічного плазмового обладнання, на жаль, має перевагу емпіричний підхід 3 великими матеріальними та трудовими витратами, коли доводиться закінчувати розробку створенням першого більш-менш працюючого, але не оптимального, варіанта. Вирішенню зазначеної проблеми присвячена дана робота. Методика та результати 3D моделювання НВЧ генератора плазми інертного газу та аналіз отриманих результатів дозволять розробити конструкцію пристрою 3 метою його інтеграції в систему магнетронного розпилення (МРC) для подальшого експериментально вивчення дослідного прототипу. Метою моделювання хвилеводно-резонаторного тракту спільно 3 камерою для генерації низькотемпературної плазми $є$ визначення геометричних параметрів НВЧ генератора, який повинен працювати сумісно з магнетронною розпилювальною системою та у якому забезпечуватиметься нижчий тип коливань і узгоджений режим роботи магнетронного генератора, від якого від- буватиметься максимальна передача енергії до області, де буде генеруватись плазма. Розроблений прототип НВЧ генератора плазми пропонується застосовувати не лише у процесах іонної обробки поверхонь твердих тіл, використовувати його для асистування магнетронному розпиленню, але і як конструктивну частину НВЧ плазмового світильника [10] та джерела швидких нейтралів [12].

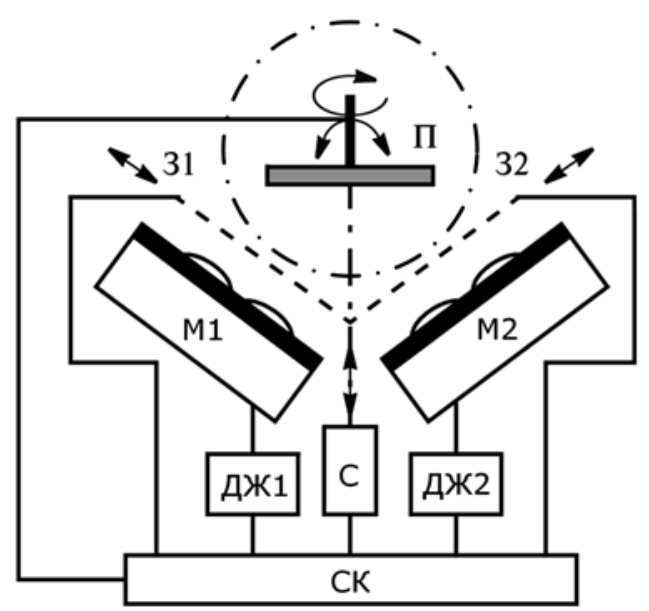

Рис. 1. Схема сумісного використання НВЧ генератора плазми 3 MPC 


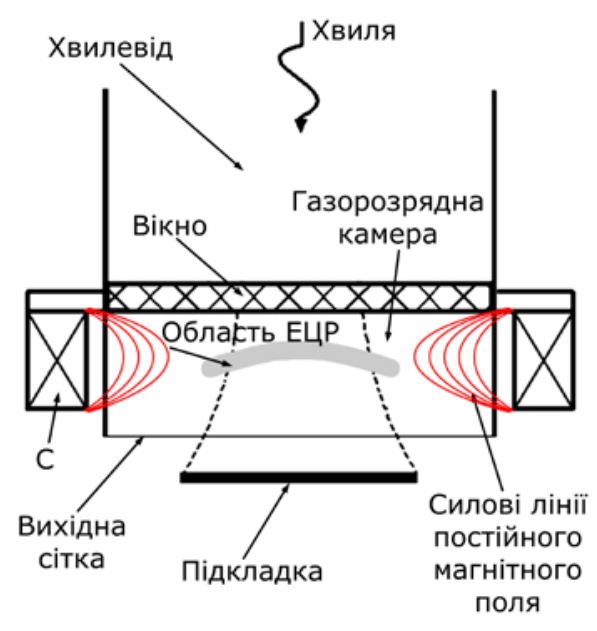

Рис. 2. Схематичне зображення нанесення тонкоплівкового покриття за допомогою НВЧ генератора плазми

\section{II. ОПИС ТЕХНОЛОГІЧНӦ СИСТЕМИ, ДЕ ВИКОРИС- ТОВУВАТИМЕТЬСЯ НВЧ ГЕНЕРАТОР ПЛАЗМИ}

На рис. 1 представлена схема сумісного використання НВЧ генератора плазми (як активатора газу) з МРС. У своєму складі установка містить два розпилювальних магнетрона M1 і М2, на які одночасно або почергово подають напругу від двох силових джерел живлення ДЖ1 і ДЖ2. Активатор розташовуватиметься над магнетронною системою (місце розташування показано штрихпунктирною лінією). Для переривання потоків розпилених частинок з мішеней магнетронів M1 і М2 на підкладку П і у період їх тренування використовують заслінки 31 і 32 (на рис. 1 заслінки показані у закритому стані). Для поточного і фінального контролю оптичних параметрів покриття використовують спектровізор С. Механічний привід підкладки забезпечує її обертання навколо власної осі і рух відносно вертикальної осі (потрібно для покращення однорідності наношуваного покриття по товщині), а також установлення підкладки паралельно площині одного або другого магнетрона. Кругові стрілки на рис. 1 показують можливі напрямки руху підкладки.

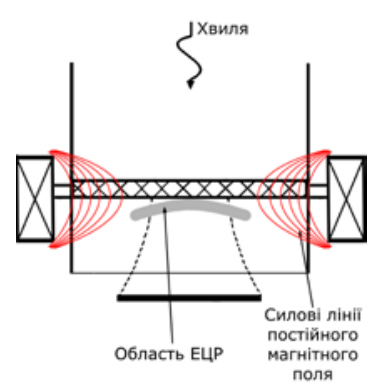

a)

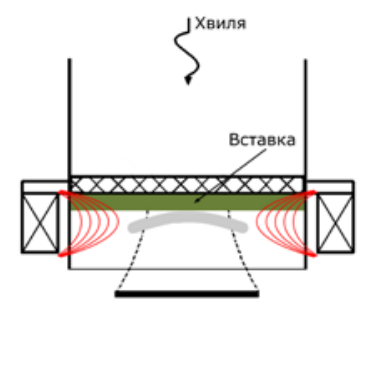

б)
Рис. 3. Зображення конструкції НВЧ генератора плазми при збільшених довжині та діаметрі соленоїда (а) та з радіопрозорою вставкою у газорозрядній камері (б)
Джерела живлення магнетронів ДЖ1 і ДЖ2 керуються за допомогою блока системи керування СК, який також управляє електричним живленням НВЧ генератора плазми, заслінками перед мішенями, електроприводом підкладки, аналізує інформацію, отримувану від спектровізора $\mathrm{C}$, і корегує роботу розпилювальної системи.

Для напуску газу до розрядної камери у конструкції НВЧ генератора плазми є отвори для підключення елементів, що створюють канал зв'язку між місцем зберігання газу та камерою іонізації.

Згідно представленої системи і технологічного місця розташування НВЧ генератора плазми для нього вибирається хвилевід круглого перерізу. Принцип роботи пристрою: НВЧ хвиля (див. рис. 2) від НВЧ джерела, поширюючись хвилеводом, потрапляє у газорозрядну камеру, проходячи радіопрозоре вікно 3 кварцового скла. Навколо газорозрядної камери розташований соленоїд для створення постійного магнітного поля, конфігурація силових ліній також показана на рис. 2.

В області, де вектори електричного та магнітного полів перпендикулярні одне одному, утворюється область електронного циклотронного резонансу (ЕЦР), у якій відбувається генерація НВЧ плазми. Плазма внаслідок плавного ослаблення магнітного поля до торців камери (див. рис. 2) "виштовхується" у сторону оброблюваної підкладки. Сітка перешкоджає виходу НВЧ випромінювання у камеру обробки.

Оскільки плазма буде поширюватись не тільки у сторону підкладки, але і у напрямку вікна, пошкоджуючи його, до того ж перешкоджаючи при цьому поширенню НВЧ хвилі до області ЕЦР, тому доцільно внести у конструкцію НВЧ генератора плазми зміни. Є два варіанти. Можна змістити максимум магнітного поля, яке створюється соленоїдами, ближче до вікна. Досягти цього можливо за допомогою збільшення довжини соленоїда, але при цьому треба буде збільшити і його діаметр на величину кріпильних елементів вікна (див. рис. 3, а).

Такі змінювання викличуть збільшення витрат на енергоживлення соленоїда та його ваги. Тому доцільніше внести у конструкцію НВЧ генератора спеціальну радіопрозору і стійку до впливу плазми вставку, яка заповнить об'єм між вікном та областю ЕЦР (див. рис. 3, б).

Шляхом комп'ютерного моделювання необхідно визначити, як такі конструктивні зміни вплинуть на розподіл електромагнітного поля у НВЧ системі, та розрахувати геометричні параметри кожної частини НВЧ генератора плазми (хвилевода, вікна, вставки та газорозрядної камери). 


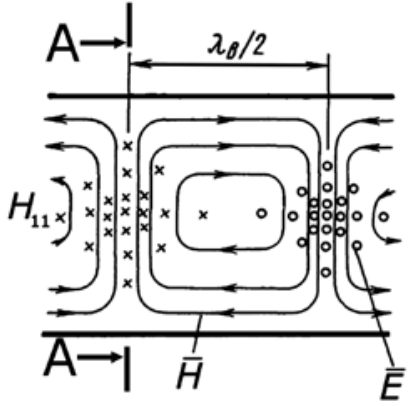

a)

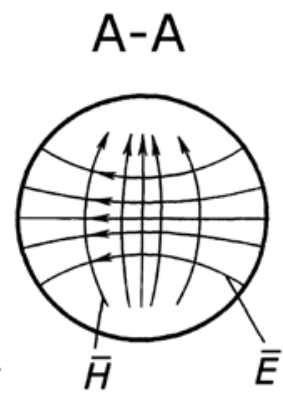

б)
Рис. 4. Зображення нижчого типу хвилі $H_{11}$ у хвилеводі круглого перерізу (картина розподілу електричних $(\boldsymbol{E})$ та магнітних $(\boldsymbol{H})$ силових ліній; а) та б) - поздовжній та поперечний перерізи хвилеводу відповідно)

\section{III. ОПИС ОБ'ЄКТУ МОДЕЛЮВАННЯ ТА ЙОГО ФІЗИКО- МАТЕМАТИЧНОЇ МОДЕЛІ}

Об'єкт моделювання (рис. 2) - НВЧ генератор 3 циліндричною газорозрядною камерою, яка відокремлена від хвилевода вікном із кварцового скла, на іншому торці знаходиться сітка для виходу плазмових частинок в технологічний об'єм.

Радіус поперечного перерізу хвилеводу визначений технологічним місцем розташування та геометричним розміром газорозрядної камери (див. пояснення у розділі II). Для забезпечення роботи хвилеводу на одному типі хвилі, що дозволить у подальшому контролювати зосередження НВЧ потужності у певній зоні, використовується нижчий тип, тобто тип, критична довжина хвилі якого має найбільшу величину. В іншому випадку існування декількох типів хвиль еквівалентно включенню між генератором і навантаженням не однієї, а декількох передавальних ліній (за числом поширюваних типів хвиль), що викликатиме порушення режиму узгодження. Якщо $\lambda$ - робоча довжина хвилі у вільному просторі, то повинні дотримуватися співвідношення:

$$
\left(\lambda_{\text {кр }}\right)_{\text {ближньої вищої хвилі }}<\boldsymbol{\lambda}<\left(\boldsymbol{\lambda}_{\text {кр }}\right)_{\text {нижчої хвилі }}
$$

Ці ж умови забезпечують найменші габарити хвилеводу. Радіус поперечного перерізу хвилеводу вибраний $R=4,1$ см. Критична довжина хвилі для циліндричного хвилеводу: $\lambda_{\text {кр }}=3,41 \cdot R=13,98 \mathrm{~cm}$.

Довжина хвилі у просторі визначається, як відношення швидкості світла $c\left(3 \cdot 10^{8} \mathrm{M} / \mathrm{c}\right)$ до частоти $f$, що генерує хвилю (у нашому випадку частота магнетронного генератора 2,45 ГГц):

$$
\lambda=c / f=3 \cdot 10^{8} / 2,45 \cdot 10^{9}=12,245 \mathrm{~cm} .
$$

При даних геометричних розмірах та частоті на етапі проектування визначено основну моду, що має розповсюджуватись у хвилеводі круглого перерізу хвиля $H_{11}$ (див. рис. 4).

Розповсюдження хвилі $H_{11}$ НВЧ трактом корисне також і тим, що при цьому вдасться організувати роботу системи у режимі ЕЦР, коли вектори електрич- ного та магнітного полів перпендикулярні одне одному, і електрони у таких умовах починають рухатись за гвинтовими траєкторіями, більше взаємодіючи 3 атомами газу у газорозрядній камері, викликаючи його іонізацію.

Довжина хвилі, що розповсюджується хвилеводом:

$$
\lambda_{\text {в }}=\frac{\lambda}{\sqrt{1-\left(\frac{\lambda}{\lambda_{\text {кр }}}\right)^{2}}}=\frac{12,245}{\sqrt{1-\left(\frac{12,245}{13,981}\right)^{2}}}=25,797 \mathrm{cм}
$$

Таким чином, переріз хвилеводу радіусом 4,1 cм відповідає умові розповсюдження хвилі типу $H_{11}$ довжиною 25,8 cм.

Тепер необхідно визначити й інші осьові розміри камери, хвилеводної частини, місце розміщення штирового виходу (антени) магнетрону... Саме ця частина роботи виконуватиметься за допомогою моделювання НВЧ генератора.

Умова розповсюдження хвиль для хвилеводу круглого перерізу у циліндричних координатах описується рівняннями [11]:

$$
\begin{aligned}
& E_{r}= \pm D \omega \mu \mu_{0} \frac{n}{r} J_{n}\left(r \frac{\mu_{n i}}{R}\right)_{\cos }^{\sin } n \varphi \\
& E_{\varphi}=D \omega \mu \mu_{0} J_{n}^{\prime}\left(r \frac{\mu_{n i}}{R}\right)_{\sin }^{\cos n \varphi} \\
& E_{z}=0 \\
& H_{r}=-D \beta \frac{\mu_{n i}}{R} J_{n}^{\prime}\left(r \frac{\mu_{n i}}{R}\right)_{\sin }^{\cos n \varphi} \\
& H_{\varphi}= \pm D \beta \frac{n}{r} J_{n}\left(r \frac{\mu_{n i}}{R}\right)_{\cos }^{\sin } n \varphi \\
& H_{z}=-j D\left(\frac{\mu_{n i}}{R}\right)^{2} J_{n}\left(r \frac{\mu_{n i}}{R}\right)_{\sin }^{\cos } n \varphi
\end{aligned}
$$

де $E_{r}, E_{\varphi}$ та $E_{z}-$ відповідно поперечна, азимутальна та осьова складові електричного поля у хвилеводі з радіусом $R ; H_{r}, H_{\varphi}$ та $H_{z}$ - поперечна, азимутальна та осьова складові магнітного поля відповідно; $D$ - константа; $\omega$ - колова частота; $\mu, \mu_{0}$ - магнітні проникності середовища та вакууму відповідно; $n$ - порядок функції; $r, \varphi, z$ - радіальна, азимутальна та осьова координати відповідно; $J$ - функція Бесселя; $\beta$ - фазова константа.

Граничні умови полягають у перетворенні дотичних складових електричного поля $E$ на стінках хвилевода, на торці та на вихідній сітці газорозрядної камери. Для цього достатньо покласти $E_{z}=0$ у зазначених ділянках.

Вихідну сітку розглядаємо як суцільну, оскільки iii отвори мають діаметр набагато менше довжини хвилі, а еванесцентні хвилі не приймаємо до уваги. 3D геометрія НВЧ генератора плазми представлена на рис. 5. Ілюстрований розв'язок рівнянь для нижчого типу хвилі $H_{11}$ наведено на рис. 4 і результат моделювання - на рис. 6. 


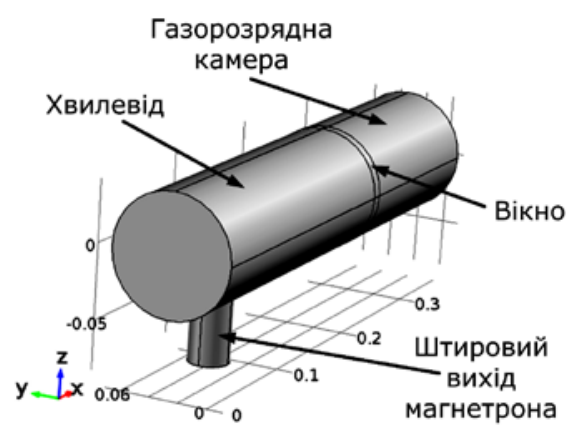

Рис. 5. Зображення 3D геометрії НВЧ генератора плазми

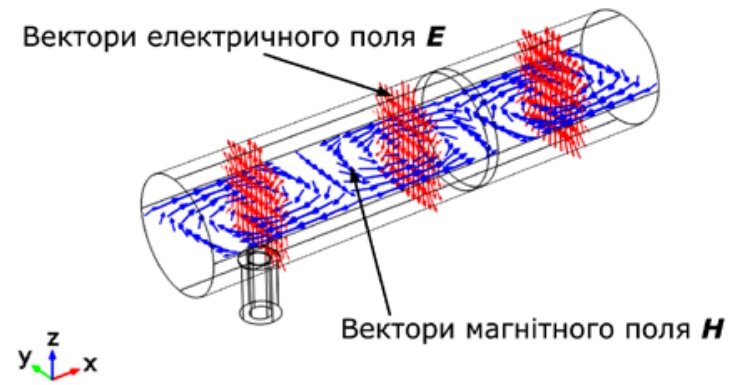

Рис. 6. Результат 3D моделювання типів хвиль, які поширюється у НВЧ системі

Середовище у хвилеводній та резонаторній частинах - вакуум. Відстань від штирового виходу магнетрона до торцевої стінки хвилевода вибрано наступним чином:

$$
\lambda_{\mathrm{B}} / 4=25,8 / 4=6,45 \mathrm{cM} .
$$

IV. З З МОДЕЛЮВАННЯ ХВИЛЕВОДНО-РЕЗОНАТОРНОГО ТРАКТУ НАДВИСОКОЧАСТОТНОГО ГЕНЕРАТОРА ПЛАЗМИ

Побудовано геометрію об'єкта (рис. 5) та виконано комп'ютерне 3D моделювання хвилеводно-резонаторного тракту НВЧ генератора плазми у середовищі фізико-інженерного пакета COMSOL Multiphysics ${ }^{\circledR}$. Вибір програмного забезпечення спирався на можливості проведення параметричних розрахунків, візуально та аналітично оцінюювати отримані результати, з великою кількістю фізико-хімічних модулів, бібліотек та іншого допоміжного матеріалу. Це набагато зручніше, ніж використання звичайних аналітичних рівнянь. Кожен етап дослідження у програмі COMSOL Multiphysics ${ }^{\circledR}$ розділений на логічні блоки, які зв'язані із вибраним модулем (у моєму випадку «Електромагнітні хвилі»), у якому проводиться розрахунок фізико-хімічних процесів. Перший блок - це створення геометрії (у моєму випадку тривимірної. Для симетричних задач можна обмежитись двовимірною) об'єкту моделювання. Кожній частині геометрії присвоюється матеріал - це другий блок. Матеріал хвилеводно-резонаторного тракту - дюралюміній. Штир магнетрону мідний. Для того, щоб розділити хвилеводно-резонаторний тракт та газорозрядну камеру, у геометрії НВЧ генератора передбачено вікно із кварцового скла, що показано на pис. 5 (для спрощення не показана частина стінки хвилеводу, яка охоплює вікно, тобто розриву стінок хвилеводу немає). Задано діелектричну проникність кварцового скла-2,09 та питому електропровідність $-1 \cdot 10^{-14} \mathrm{Cm} /$ м. Діелектрична $\varepsilon$ та магнітна $\mu$ проникності вакууму становлять 1 , питома електропровідність дюралюмінію - 2,33· $10^{7} \mathrm{CM} / \mathrm{M}$. Простір розрахунку обмежується 3D геометрією. Параметри НВЧ хвилі: частота 2,45 ГГц, потужність 900 Вт.

Далі починається етап створення розрахункової сітки, граничної кількості відліків. Існує спеціальна методика вибору форми вузлів сітки. У програмному забезпеченні для користувача передбачена довідка стосовно найпоширеніших питань, які можуть виникнути при роботі. Також присутні різного роду підказки та попередження, наприклад, якщо не було задано матеріал якогось елементу конструкції або задана недостатня кількість вузлів сітки для проведення розрахунку, що може призвести до помилок обчислень... У моєму випадку я скористувався стандартними зразками при автопобудові сітки для основних елементів геометрії, і для деяких дрібних елементів - застосував деталізованішу. Результат представлений на рис. 7.

Виконавши моделювання та перевіривши, що хвилеводом, дійсно, поширюється нижчий тип хвилі $H_{11}$ (рис. 6) і не поширюються інші типи, впевнюємось, що зазначені у розділі III вимоги виконані.

Далі шляхом моделювання підбирається довжина резонаторної системи таким чином, щоб виконувалась умова узгодження, максимум електромагнітного поля повинен знаходитись посередині газорозрядної камери.

\section{V. РЕЗУЛЬТАТИ МОДЕЛЮВАННЯ ТА ОБГОВОРЕННЯ}

Вибір геометричних розмірів НВЧ елементів генератора виконаний за допомогою 3D моделювання в середовищі фізико-інженерного пакета COMSOL Multiphysics ${ }^{\circledR}$. У генераторі встановлюється резонаторний режим з передачею НВЧ потужності від магнетрона до області розрядної камери, де буде відбуватись генерація плазми, при відповідно вибраній геометрії хвилеводно-резонаторного вузла, який разом 3 картиною розподілу електромагнітного поля представлений на рис. 8.

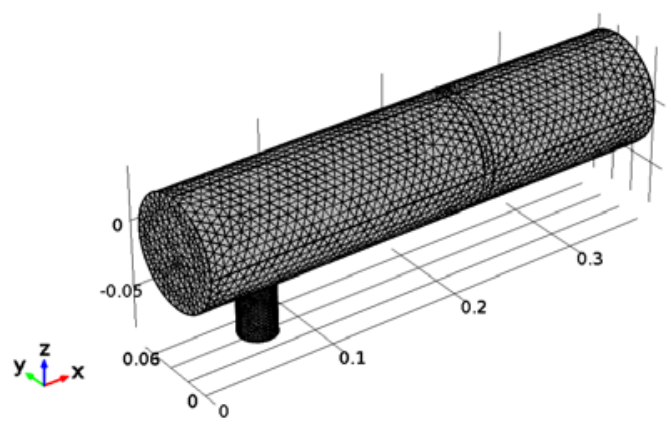

Рис. 7. Результат побудови розрахункової сітки 


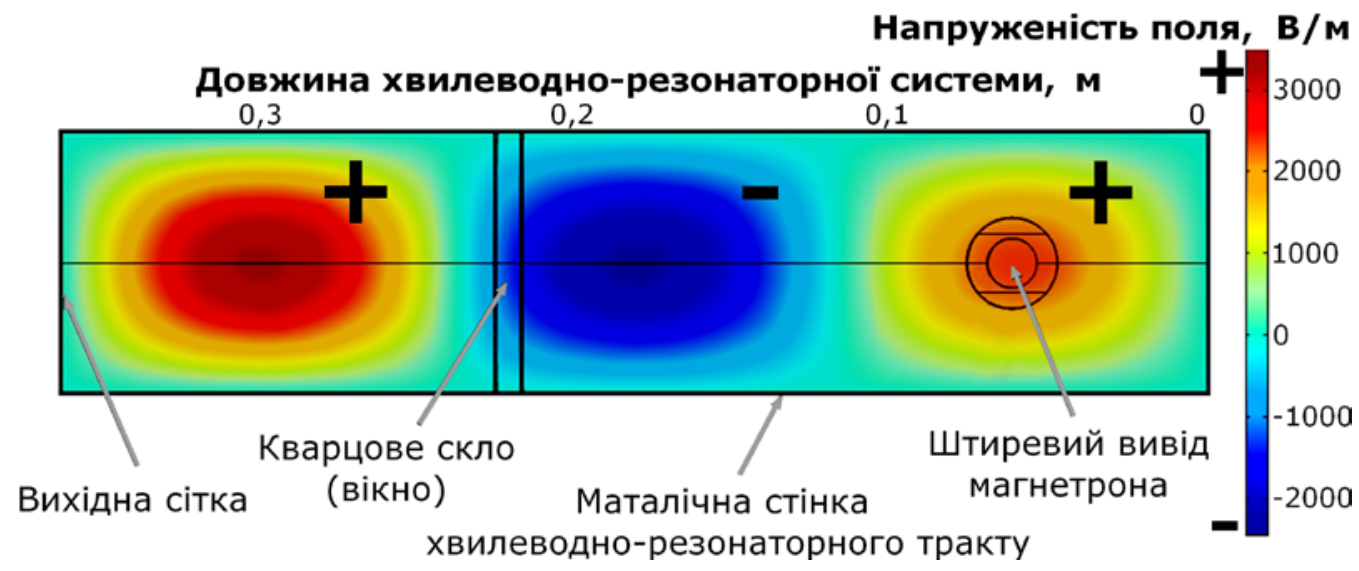

Рис. 8 Результати 3D моделювання хвилеводно-резонаторної частини НВЧ генератора плазми

Як видно з рисунку, у хвилеводно-резонаторному тракті встановлюється режим стійної хвилі типу $H_{113}$. Максимум напруженості електричного поля розташований на відстані 30 см. На цьому рівні буде розміщений соленоїд для створення постійного магнітного поля. Вивід енергії магнетрона розташований на відстані $\lambda / 4$ від торця хвилеводу. Судячи із результатів моделювання, така умова дозволяє вивести магнетрон із режиму короткого замкнення у режим холостого ходу на НВЧ. Розміри конструктивних елементів (при радіусі 4,1 см): хвилевід - 21,5 см, вікно - 0,8 cм, газорозрядна камера - 13,8 см. Загальна довжина НВЧ генератора плазми - 36,1 см.

Як було описано у розділі III, введення фторопластового блоку в область між вікном та областю ЕЦР до- зволяє більш ефективно використовувати об'єм плазми, який буде створюватись у процесі генерації. Фторопласт $є$ радіопрозорим для НВЧ і вносить малі втрати при проходженні через нього електромагнітної хвилі. Застосовувати фторопласт як практичне рішення для даних цілей не $\epsilon$ доцільно, лише - як приклад для пробних експериментів. У результаті моделювання враховано зміну електромагнітного поля, завдяки чому уточнено розміри НВЧ системи та розраховано розмір фторопластового блоку (циліндр діаметром, рівним внутрішньому діаметру хвилеводу: $8,2 \mathrm{~cm}$; висотою $10 \mathrm{~cm}$ ).

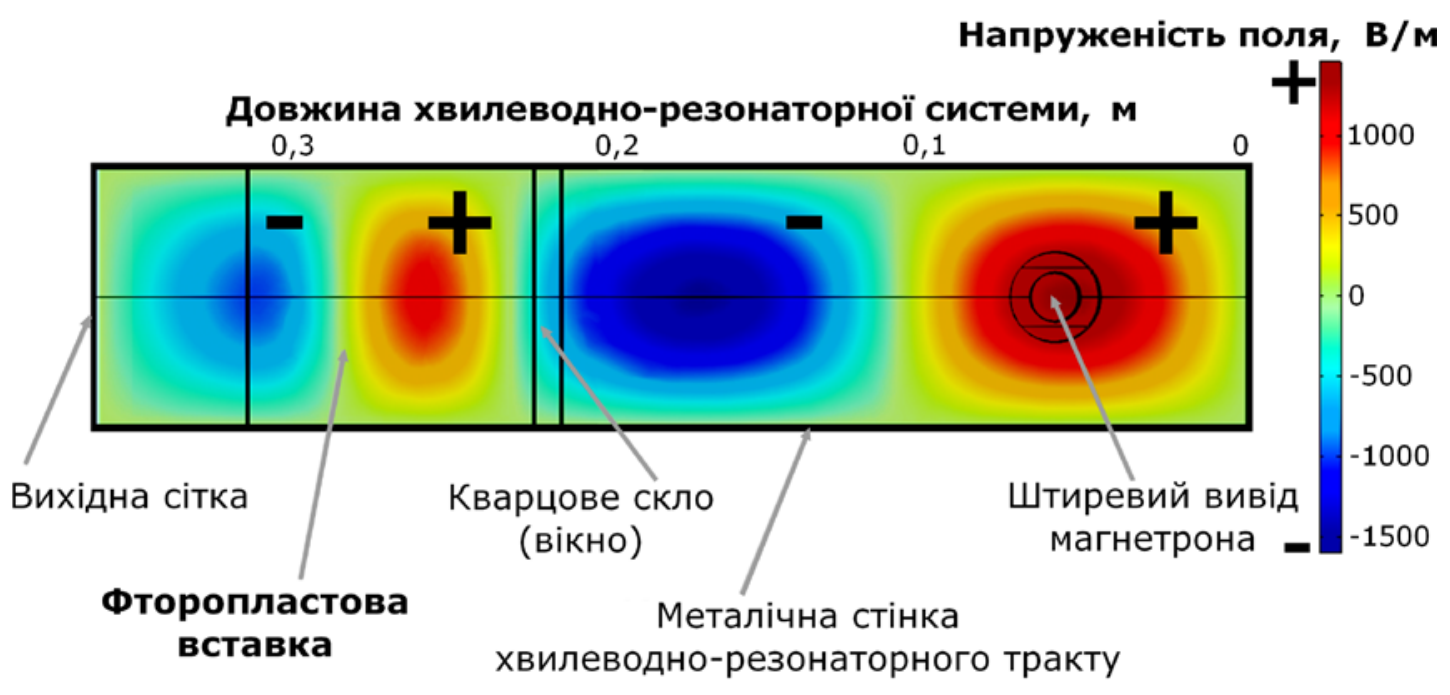

Рис. 9. Результати 3D моделювання хвилеводно-резонаторної частини НВЧ генератора плазми з фторопластовою вставкою у розрядній камері 
На рис. 9 показана картина розподілу електромагнітного поля у резонаторі до початку виникнення розряду. Як видно, у хвилеводно-резонаторному тракті встановлюється режим стійної хвилі типу $H_{114}$.

На базі результатів моделювання розроблено креслення НВЧ генератора плазми. При роботі у режимі електронного циклотронного резонансу навколо газорозрядної камери буде знаходитись соленоїд, за допомогою якого також здійснюватиметься управління густиною струму іонів. Під дією ЕЦР відбувається прискорення електронів, що рухаються за кільцевими траєкторіями, при цьому має місце взаємодія їх 3 магнітним полем.

Для генерації НВЧ потужності використовується магнетрон фірми $L G$ моделі 2M214 з наступними параметрами: вихідна частота - 2,45 ГГц, потужність НВЧ $P_{\mathrm{HBч}}=900 \mathrm{BT}$, анодна напруга $U_{\mathrm{a}-\kappa}=4$ кВ.

\section{Висновки}

Виконано фізико-топологічне 3D моделювання «холодного» (дорозрядного, допробійного) режиму роботи НВЧ генератора плазми для іонно-плазмової технології 3 використанням апарату COMSOL Multiphysics ${ }^{\circledR}$. Модель базується на рівняннях, що описують поширення електромагнітної хвилі у хвилеводно-резонаторній системі від штирової антени НВЧ магнетрона до циліндричної газорозрядної камери через діелектричне вікно, яке розділяє атмосферну і вакуумну частини генератора плазми. За результатами моделювання були уточнені попередньо вибрані геометричні розміри хвилеводно-резонаторної системи і виготовлений дослідний зразок НВЧ генератора (перші випробування якого підтвердили його працездатність). Була вдосконалена конструкція генератора шляхом введення додаткового діелектричного (фторопластового) блоку в об'єм розрядної камери, що прилягає до діелектричного вікна. Розроблений генератор плазми використовуватиметься для активації інертного газу для іонної обробки поверхні підкладки.

\section{ПЕРЕЛІК ПОСИЛАНЬ}

[1] A. Azarenkov, V. Beresnev and A. Pogrebniak, Struktura i vlastyvosti zahysnyh pokryttiv i modyfikovanyh shariv materialiv [The structure and properties of the protective coating layers and modified materials], Kharkiv: Karazin KNU, 2007, p. 560. ISBN: 978-966-623-476-9

Надійшла до редакції 25 червня 2017 р.
[2] E. Dabyzha, N. Novikov, N. Borysova, I. Bondar, V. Dabyzha and A. Zolotukhin, «Suchasni vakuumni texnologiyi oderzhannya pokryttiv [Up-to-date vacuum technology for coatings production],» Suchasna electrometallurgia, no. 4, pp. 34-40, 2005.

[3] «Method magnetronnogo napilennya pokrittiv $\mathrm{z}$ ionnym asystuvannyam [Method of magnetron coating deposition with ion assisting],» 2009. [Online]. Available: http://cozap.com.ua/text/9625/index-1.html. [Accessed: 07 December 2015].

[4] B. Lyashenko, V. Mirnenko, L. Golovko and M. Boleyko, «Keruvannya parametramy nanesennya vakuum-plazmovyh pokryttiv z metoyu pidvyshchennya yih harakterystyk mitsnosti i plastychnosti [Control of parameters for applying vacuum plasma coatings to improve their strength and ductility characteristics],» Naukovi Visti NTUU "KPI", no. 5, pp. 49-54, 2005.

[5] V. Beresnev, D. Perlov and A. Fedorenko, Ekologichno bezpechne vakuumno-plazmove obladnannya i texnologiyi nanesennya pokryttiv [Sustainable vacuum plasma equipment and coating technology], Kharkiv: KISP, 2010, p. 292.

[6] A. Demchyshyn, Y. Kurapov, A. Goncharov, V. Mychenko, E. Kostin and E. Ternovoy, «Doslidna ionno-plazmova ustanovka dlya nanesennya pokryttiv u vakuumi [Pilot ionplasma unit for coatings deposition in vacuum],» Problemy spets. metalurhii, no. 4, pp. 41-43, 2001.

[7] O. Volpyan, A. Kuzmichev и A. Samokysh, «Sovremennye opticheskie plenochnye pokrytiya [Up-to-date optical film coatings],» Electronics and communications, vol. 13, no. 5 (46), pp. 5-19, 2008.

[8] A. Kuzmichev, Magnetronnye raspylitel'nye sistemy [Magnetron sputtering systems], vol. 1, Kyiv: Avers, 2008. ISBN: 966-893407-5

[9] R. Yafarov, Fyzyka SVCh vakuumno-plazmennyh nanotexnologyi [Physics of microwave vacuum-plasma nanotechnologies], Moskva: Phizmalit, 2009, p. 216. ISBN: 978-59221-1150-8

[10] A. Kuzmichev, V. Perevertailo and A. Mumladze, «SVCh gazorazriadnyi svetilnik na parah sery [Microwave gas-discharge sulfur vapor lamp],» Electronics and communications, vol.. 20, no. 5 (20), pp. 15-21, 2015. DOI: $10.20535 / 2312-$ 1807.2015.20.5.69930

[11] I. Lebedev, Technica i pribory SVCh [MW equipment and devices], Moskva: Vysshaia shkola, 1970, $440 \mathrm{p}$.

[12] V. Perevertailo, A. Kuzmichev, «Modeluvannia plazmovych djerel shvydkyh neitraliv [Simulation of fast neutrals plasma sources],» in Proc. of $10^{\text {th }}$ theoretical and practical conference Perspektyvni napriamky suchasnoi electroniky, Kyiv, Ukraine, pp. 33-40, 7-8 April 2016.

\section{Моделирование сверхвысокочастотного генератора плазмы}


Перевертайло В. В., ORCID 0000-0001-5706-5946

e-mail vladimir_mj@ukr.net

Национальный технический университет Украины

"Киевский политехнический институт имени Игоря Сикорского" kpi.ua

Киев, Украина

Реферат-Представлены результаты 3D моделирования волноводно-резонаторного тракта совместно с газоразрядной камерой, путем чего были рассчитаны геометрические параметры СВЧ генератора в согласованном режиме с максимальной передачей энергии от источника СВЧ мощности в область, где будет происходить генерация плазмы. Расчет проводился, исходя из условия дальнейшего совместного использования устройства с системой магнетронного распыления и предназначен он для активации инертного газа. В данной работе представлен анализ составных частей генератора плазмы с учетом расчетов, представлено описание схемы работы системы и принцип работы СВЧ генератора плазмы

Библ. 12, рис. 9.

Ключевые слова - сверхвысокочастотный генератор плазмы; 3D моделирование; СВЧ тракт; волновод.

UDC 621.38

\title{
Simulation of microwave plasma generator
}

\author{
V. V. Perevertailo, ORCID 0000-0001-5706-5946 \\ e-mail vladimir_mj@ukr.net \\ National technical university of Ukraine “Igor Sikorsky Kyiv polytechnic institute” kpi.ua \\ Kyiv, Ukraine
}

\begin{abstract}
Results of 3D simulation of the waveguide resonator tract together with the gas-discharge chamber were presented. On the basis of simulation the geometric parameters of the microwave generator in the matched mode with the maximum transmission of energy from the source of the microwave power to the region where the plasma generation will be obtained is calculated. The calculation was made on the basis of the condition for further combined use of the device with the magnetron sputtering system and it is intended for the activation of inert gas. In this paper, an analysis of the geometrical parameters of the plasma generator, taking into account the calculations, the scheme of the system and the principle of operation of the microwave generator plasma were described. Simulated microwave plasma generator has a wide range of applications, in particular, it can be used in solid surface treatment as an independent device, also as assisting device with the magnetron puttering system (thin-film coatings deposition, modification of the surface layer or its removal), or as part of the source of high-energy neutrals (very important in treatment of dielectric coatings), or in a microwave plasma lighting devices (general and special purposes). Vacuum-plasma methods - one of the most promising methods of coating deposition. Causes of that are their environmental safety, high purity of technological processes and product quality. It was possible to expand the opportunities of the method due to use of magnetron sputtering systems (MSS) and ion sources which generate directed streams of ions (both inert and chemically active) of working gases accelerated to certain energy. This in turn allows us to use them for cleaning of the substrates surface and influence of the ion flow on the coating during its growth to change its structure. Optical coatings are most often thin film dielectric of complex composition in the form of oxides, nitrides, carbides and their combinations, which are applied to the substrate in the reaction gas environment. Activation of gas is especially necessary when the source medium (source) in the form of unreacted metals and semiconductors is used. The best ways to stimulate the synthesis of optical coatings are nonthermal methods - the activation of gas in plasma of an electric discharge, followed by feeding to the substrate surface, its bombardment with gas ions and ultraviolet radiation.
\end{abstract}

Ref. 12, fig. 9.

Keywords - microwave plasma generator; 3D simulation; microwave path; waveguide. 